\title{
Beneficial effects of combined therapy with lacidipine and candesartan in obese hypertensive patients
}

\author{
TATIANA ASHCHEULOVA, NINA GERASIMCHUK, OLGA KOVALYOVA, OLEKSII HONCHAR \\ Kharkiv National Medic University, Nauky Ave., 4, Kharkiv, 61022, Ukraine
}

\begin{abstract}
Introduction. Obesity is becoming one of the leading risk factors of coronary heart disease, hypertension, cerebrovascular disease. Despite the presence of a large number of antihypertensive agents and scientific substantiation of antihypertensive treatment principles it would be wrong to assume that the problem is completely solved. Development of endothelial dysfunction is one of the key pathogenic mechanisms in hypertension. This process is proven to have contributed by immune inflammation activation which is mediated by pro-inflammatory cytokines and oxidative stress.

Aims. To investigate the additional benefits of the combined antihypertensive therapy with lacidipine and candesartan on the basis of studying their antioxidant properties, impact on endothelial function and pro-inflammatory cytokines activity in hypertensive patients with overweight and obesity.

Methods. A combination of a calcium channel blocker and angiotensin receptor blocker (lacidipine $2 \mathrm{mg}, 4 \mathrm{mg}$, and candesartan $4 \mathrm{mg}, 8 \mathrm{mg}, 16 \mathrm{mg}$ ) was prescribed to 30 patients with essential hypertension of grades $1-3,30$ to 65 years old (mean age $-54.7 \pm 5.8$ years), who previously have not been receiving regular antihypertensive therapy.

Results. During the course of combined antihypertensive therapy with lacidipine and candesartan, a significant reduction in i-NOS activity, TNF- $\alpha$ to its type I soluble receptor ratio (TNF$\alpha / \mathrm{sTNF}-\alpha \mathrm{RI}$ ), and oxidative stress marker -8 -iso-PgF $2 \alpha$ has been observed. Activity of e-NOS, levels of SOD and catalase, in contrast, have increased by the end of observation period.

Conclusion. The improvement of endothelial function due to lower level of oxidative stress and a significant decrease of immune activation has been observed in hypertensive patients with overweight and obesity under the influence of combined antihypertensive therapy with lacidipine and candesartan.
\end{abstract}

Keywords: hypertension, obesity, oxidative stress, nitric oxide synthase, tumor necrosis factor- $\alpha$, catalase, lacidipine, candesartan.

\section{INTRODUCTION}

Cardiovascular diseases remain a prominent cause of mortality (a leading cause in most developing countries), with hypertension being one of the most prevalent risk factors. According to [1], aggressive blood pressure (BP) lowering leads to a significant decrease in the rate of major adverse cardiovascular events (MACE), including myocardial infarction and stroke, compared to those with less intensive anti-hypertensive treatment, justifying further research in the field of new diagnostic approaches as well as therapeutic strategies.

Obesity is another major and highly prevalent risk factor for developing cardiovascular pathology, including hypertension (the incidence of which increases up to $55 \%$ [2], coronary heart disease (CHD), and cerebrovascular disease. The rate of the growth of obesity in high-income countries had become alarming during the last decades, giving the public health experts the possibility to compare it with an epidemic.

Endothelial dysfunction (ED) can be defined as the shift of the properties of the endothelium toward a phenotype characterized by impaired vasodilation and a proinflammatory and prothrombic status [3]. ED is generally driven by a reduction in endotheliocytes' NO eNOS-related synthetic capacity as well as an increased rate of its degradation in the oxidative stress (OS) conditions, and is one of important links in the pathogenesis of hypertension [4]. ED is regarded as both a result of direct target organ damage and the sign of vascular dysfunction that contributes to an increase in BP, forming the pathogenic circle in hypertensive patients.

Both ED and OS may therefore be considered as therapeutic targets in patients with hypertension. Prevention of NO-induced cellular toxicity driven by its hyperproduction through inducible pathway might be achieved with the action of endogenous 
and exogenous antioxidants limiting excessive NO interaction with superoxide anions. OS is also considered a potential promotor of pro-inflammatory cytokines system, with tumor necrosis factor- $\alpha$ (TNF- $\alpha$ ) hyperproduction playing a prominent role in pathophysiology of hypertension $[5,6]$. Most studies that analyze pharmacological properties of antihypertensive agents fail to cover the aforementioned aspect of their action.

Showing the strongest correlations with outcomes, achieving of the target BP is considered to be the most important goal in the treatment of hypertension, which often becomes a problem in overweight and obese patients. Therefore, in a lot of cases, there is a need for the use of two or more mutually complementing antihypertensive agents with different mechanisms of action, all of which should be metabolically neutral, considering an increased risk of developing diabetes in patients with obesity [7-9].

Thus, further study of combined antihypertensive treatment regimens in patients with overweight and obesity in the context of their effect on the endothelial function should be considered a relevant task of medical science, solving of which bears potential benefits for routine clinical practice.

Purpose. To investigate the additional benefits of the combined antihypertensive therapy with lacidipine and candesartan on the basis of studying their antioxidant properties, impact on endothelial function and pro-inflammatory cytokines activity in hypertensive patients with overweight and obesity.

\section{MATERIALS AND METHODS}

A combination of a calcium channel blocker (CCB) and angiotensin receptor blocker (ARB) (lacidipine $2 \mathrm{mg}, 4 \mathrm{mg}$ and candesartan $4 \mathrm{mg}$, $8 \mathrm{mg}, 16 \mathrm{mg}$ ) was prescribed to 30 patients with essential hypertension of grades 1-3, 30 to 65 years old (mean age $-54.7 \pm 5.8$ years), who previously have not been receiving regular antihypertensive therapy. The control group included 16 age- and sex-matched healthy subjects. The informed consent was obtained from all participants of the study.

The fasting blood samples were taken twice during in-hospital period, with the first one obtained the next day after the patient's admission to hospital, and the second one after 2 weeks of treatment, prior to discharge $(n=30)$. In a part of the study group $(\mathrm{n}=10)$, a control visit was conducted after 8 weeks from the start of treatment, with repeated blood sampling. Other patients have been excluded from the study due to a set of reasons that included failure to show at the control visit, lack of compliance or alterations made to the prescribed treatment regimen in the post-discharge period.

Blood sampling was performed from the cubital vein. All patients were similar in terms of physical activity, did not take any nitro-containing drugs, and did not eat foods rich in nitrates and nitrites that could affect the activity of nitric oxide system.

The guidelines by of European Society of Hypertension (ESH)/European Society of Cardiology (ESC) (2013) were used for verification of the diagnosis and estimation of the hypertension grade [10]. Exclusion criteria were: secondary hypertension, associated inflammatory and endocrine disorders, as well as other conditions that could have an impact on the activity of oxidative processes. Of the patients that have been enrolled to study, 8 have been diagnosed with essential hypertension of grade 1, 15 - of grade 2, and 7 - of grade 3 .

In addition to the standard examination protocol, anthropometric measurements (height, weight, waist and hips circumference) have been performed with the calculation of body mass index (BMI, $\mathrm{kg} / \mathrm{m}^{2}$ ), waist to hips ratio $(\mathrm{W} / \mathrm{H})$ in order to determine the presence of excessive body weight and grade of obesity, as well as type of fat distribution. The WHO classification of obesity has been used [11] with patients with BMI in the range of $25-29.9 \mathrm{~kg} / \mathrm{m}^{2}$ being defined as overweight, BMI of $30-34.9 \mathrm{~kg} / \mathrm{m}^{2}$ as those with class 1 obesity, BMI of $35-39.9 \mathrm{~kg} / \mathrm{m}^{2}-$ class 2 obesity, BMI of $\geq 40 \mathrm{~kg} / \mathrm{m}^{2}$ - class 3 obesity. The waist circumference of more than $88 \mathrm{~cm}$ for female and $102 \mathrm{~cm}$ for male patients was considered a sign of abdominal obesity. Waist to hips ratio was used to define the fat distribution type, with the values of $>0.85$ for female and $>0.90$ for male patients attesting to the presence of abdominal (visceral, central) type, values of $<0.80$ - gynoid (peripheral) type, and the rest of patients falling into the intermediate type category.

Of the patients enrolled to study, 11 were overweight and 19 had obesity of varying severity: class 1 was observed in 9 patients, class 2 - in 8 , and class 3 - in 2 patients.

The endothelial functional state on the background of combined therapy was studied by evaluating the activity of endothelial and inducible NO-synthase. Determining the state of pro-oxidant and antioxidant systems in the dynamics of treatment in this group of patients was based on the analysis of 8-isoprostane level $(\mathrm{n}=14$, control group $\mathrm{n}=10)$, 
superoxide dismutase (SOD), and catalase activity. According to the current data, 8-isoprostane (8-IP) is considered one of the most specific markers allowing to asses the level of free radicals (FR) production with a sufficient degree of accuracy, reliability and reproducibility of the results. 8-IP is a product of metabolism in peroxidation of arachidonic acid which is isomerical to prostaglandin F2 $\alpha$ [12].

Immune activation during therapy with candesartan and lacidipine was assessed by evaluating the serum levels of TNF- $\alpha$ and its type I soluble receptor (sTNF- $\alpha$ RI) in all subjects.

The concentration of NO-synthases (NOS), SOD, and catalase activity was determined biochemically.

The contents of serum 8 -iso-PgF2 $\alpha$ (8-isoprostane), TNF-alpha and its type I soluble receptor (sTNF- $\alpha \mathrm{RI})$ were determined in all subjects using the "8-isoprostane ELISA" (Usbiological, USA), "ProCon TNFa" (Protein contour, Russian Federation) and "sTNF-RI EASIA" (BioSource Europe SA, Belgium) ELISA kits, respectively.

Statistical analysis of the study results was performed using Statsoft Inc. Statistica for Windows v.6.0 software package. The obtained results are presented as mean value (Mean) \pm standard deviation
(SD). To evaluate the discrepancies between study groups, $t$-test was used, with $p$ levels less than 0.05 being considered as significant.

\section{RESULTS}

Initial levels of evaluated parameters before the onset of treatment are presented in Table 1. A significant increase of the i-NOS activity, proinflammatory cytokines (TNF- $\alpha$, sTNF-RI) levels, as well as markers of oxidative stress - 8-iso-PgF2 $\alpha$ was found in the patients of the study group compared to control. In contrast, serum activity of e-NOS and SOD was decreased in patients with essential hypertension and associated obesity. There was no significant difference in catalase activity between groups.

The activity of e-NOS was reduced by $5.6 \%$ and $11.7 \%(0.738 \pm 0.10, \mathrm{p}>0.05$ and $0.694 \pm$ $0.12, \mathrm{p}<0.05$ vs $0.782 \pm 0.045$ the control group) in overweight patients $(\mathrm{n}=11)$ and obese patients $(\mathrm{n}=19)$, respectively.

The dynamics of the assessed parameters during the course of combined antihypertensive therapy is presented in Table 2 .

Table 1

Levels of TNF- $\alpha$, sTNF- $\alpha$ RI, 8 -isoprostane, activity of i-NOS, e-NOS, SOD and catalase in hypertensive patients with obesity $v s$ control group

\begin{tabular}{|lcc|}
\hline \multicolumn{1}{|c|}{ Parameter } & Control group & Patients \\
\hline TNF- $\alpha(\mathrm{pg} / \mathrm{mL})$ & $13.23 \pm 3.40$ & $132.64 \pm 22.58^{*}$ \\
\hline sTNF- $\alpha$ RI $(\mathrm{ng} / \mathrm{mL})$ & $1.20 \pm 0.60$ & $2.10 \pm 0.16^{*}$ \\
\hline 8-isoprostan $(\mathrm{ng} / \mathrm{mL})$ & $1.41 \pm 0.25$ & $12.67 \pm 9.63^{*}$ \\
\hline i-NOS $(\mathrm{pmol} /(\mathrm{min} . \times \mathrm{mg}$ of protein) & $0.208 \pm 0.089$ & $0.588 \pm 0.08^{*}$ \\
\hline e-NOS $(\mathrm{pmol} /(\mathrm{min} . \times$ mg of protein) & $0.782 \pm 0.045$ & $0.720 \pm 0.12^{* *}$ \\
\hline SOD $(\mu \mathrm{catal} / \mathrm{L})$ & $0.54 \pm 0.05$ & $0.417 \pm 0.11^{*}$ \\
\hline catalase $(\mu \mathrm{catal} / \mathrm{L})$ & $3.338 \pm 0.39$ & $3.50 \pm 1.7^{* *}$ \\
\hline
\end{tabular}

Note: ${ }^{*}-\mathrm{p}<0.05$ vs control group; ${ }^{* *}$ - $\mathrm{p}>0.05$ vs control group

Table 2

Endothelial functional state and oxidative stress dynamics during the course of combined therapy with lacidipine and candesartan in hypertensive patients with obesity

\begin{tabular}{|lccc|}
\hline \multicolumn{1}{|c}{ Parameter } & $\begin{array}{c}\text { Before treatment } \\
(\mathbf{n}=\mathbf{3 0})\end{array}$ & $\begin{array}{c}\text { After 2 weeks of } \\
\text { treatment }(\mathbf{n}=\mathbf{3 0})\end{array}$ & $\begin{array}{c}\mathbf{8} \text { weeks after the start } \\
\text { of treatment }(\mathbf{n}=\mathbf{1 0})\end{array}$ \\
\hline i-NOS $(\mathrm{pmol} /(\mathrm{min} . \times \mathrm{mg}$ of protein) & $0.588 \pm 0.08$ & $0.532 \pm 0.07^{*}$ & $0.514 \pm 0.09^{*}$ \\
\hline e-NOS $(\mathrm{pmol} /(\mathrm{min} . \times \mathrm{mg}$ of protein) & $0.720 \pm 0.12$ & $0.767 \pm 0.12^{*}$ & $0.802 \pm 0.14^{*}$ \\
\hline 8-isoprostan $(\mathrm{ng} / \mathrm{mL})(\mathrm{n}=14)$ & $12.67 \pm 9.63$ & $9.51 \pm 7.42^{*}$ & $2.42 \pm 1.49^{*}$ \\
\hline SOD $(\mu \mathrm{catal} / \mathrm{L})$ & $0.417 \pm 0.11$ & $0.532 \pm 0.15^{*}$ & $0.559 \pm 0.124^{*}$ \\
\hline catalase $(\mu \mathrm{catal} / \mathrm{L})$ & $3.50 \pm 1.7$ & $4.45 \pm 1.3^{*}$ & $4.26 \pm 1.65^{\#}$ \\
\hline
\end{tabular}

Note: ${ }^{*}-\mathrm{p}<0.05 v$ levels before treatment, ${ }^{\#}-\mathrm{p}=0.05$ vs levels before treatment

In the group of surveyed patients with hypertension, a change in the ratio of NOS isoforms activity was observed during the course of lacidipine/ candesartan treatment. The activity of i-NOS was significantly reduced by $9 \%(0.532 \pm 0.07 v s .0 .588 \pm$ $0.08 \mathrm{pmol} / \mathrm{min} . \times \mathrm{mg}$ of protein prior to treatment) and $13 \%(0.514 \pm 0.09$ vs. $0.591 \pm 0.109$ prior to treatment) after the 2 and after 8 weeks of treatment, 
respectively, $p<0.05$. The activity of e-NOS, on the contrary, was showing a significant increase by $6 \%(0.767 \pm 0.12$ vs. $0.720 \pm 0.12 \mathrm{pmol} / \mathrm{min} . \times \mathrm{mg}$ of protein compared to the level before treatment) and $14 \%(0.802 \pm 0.14 v s .0 .704 \pm 0.123$ compared to the level before treatment) after the 2 and after 8 weeks of therapy, $p<0.05$. Thus, the changes observed during the course of the applied scheme of combined antihypertensive therapy indirectly indicated the improvement of the functional state of endothelium.

During the course of treatment with combination of lacidipine and candesartan in hypertensive patients with overweight and obesity, we have also observed a change in the SOD and catalase activity. The obtained data indicates that the SOD activity in the period of hospital treatment was significantly increased by $28 \%(0.532 \pm 0.15$ vs $0.417 \pm 0.11)$ and by $36 \%$ after 8 weeks of treatment $(0.559 \pm 0.124$ vs $0.410 \pm$ $0.125 \mu \mathrm{catal} / \mathrm{L}$ prior to treatment, $\mathrm{p}<0.05$. A significant increase in the catalase activity was also prominent both during the hospital treatment period by $27.1 \%(4.45 \pm 1.3 v s 3.5 \pm 1.7 \mu \mathrm{catal} / \mathrm{L}$ before treatment, $\mathrm{p}<0.05)$ and 8 weeks after the start of treatment- by $26.8 \%(4.26 \pm 1.65$ vs $3.36 \pm 2.07$, $\mathrm{p}=0.05)$.

Analysing the level of 8-isoprostane as the main marker of oxidative stress, a decrease of its serum level by $25 \%(9.51 \pm 7.42$ vs. $12.67 \pm 9.63 \mathrm{ng} /$ $\mathrm{mL}, \mathrm{p}<0.05$ ) has been observed during 2 weeks after the start of treatment in a hospital. After 8 weeks of treatment, 8-isoprostane levels had been decreased by $79 \%$ (down to $2.42 \pm 1.49$ ) compared to at baseline.

These facts testify to the beneficial effects of the studied scheme of antihypertensive therapy on the level of 8 -isoprostane. It should be also noted that after 2 months serum 8-isoprostane level was approaching the levels of the control group.

Analysis of the pro-inflammatory cytokines activity has shown that 8 weeks treatment with a lacidipine/candesartan led to $66 \%$ decrease of mean TNF- $\alpha$ levels by $87.65 \mathrm{pg} / \mathrm{mL}(44.99 \pm 5.63$ vs $132.64 \pm 22.58, \mathrm{p}<0.05)$ compared to baseline prior to treatment. sTNF- $\alpha$ RI showed the opposite trend, increasing its mean levels by $0.53 \mathrm{ng} / \mathrm{mL}$ $(25 \%)(2.63 \pm 0.53$ vs $2.10 \pm 0.16)$ during the course of treatment. The decrease in TNF- $\alpha / \mathrm{sTNF}-$ $\alpha \mathrm{RI}$ ligand/receptor ratio by 46.03 (73\%) (17.11 vs 63.14) indicates a significant decrease in the autoimmune activation level under the influence of 8 weeks treatment with $\mathrm{ARB}+\mathrm{CCB}$.
During the course of treatment the patients generally had been noting the improvement of general feeling, the reduction of intensity and frequency of headaches, dizziness, pain in the heart region, fatigue, increase in the exercise tolerance. All patients who had been receiving treatment were discharged from the hospital in satisfactory general condition. The treatment contributed to a significant reduction in blood pressure levels as well as a lack of significant effect on heart rate (HR), which reaffirms the advantage of lacidipine in this regard compared to other CCB [13]. The features of the hemodynamic changes on the background of candesartan/lacidipine treatment are presented in Table 3.

In the group of patients treated with candesartan and lacidipine, a reduction in the mean values of office SBP by $44.5 \mathrm{mmHg}$ and office DBP by 29.9 $\mathrm{mmHg}$ was observed during the hospital treatment period. The average mean BP level has been decreased by $34.8 \mathrm{mmHg}$, pulse pressure (PP) - by $15.2 \mathrm{mmHg}$, which corresponded to $25 \%, 28 \%$, $27 \%$, and $21 \%$ reduction, respectively, compared with the levels before the onset of treatment $(\mathrm{p}<$ 0.05 for all parameters).

Table 3

Blood pressure and heart rate dynamics during the course of candesartan/lacidipine treatment $($ Mean \pm SD)

\begin{tabular}{|lc|}
\hline \multicolumn{1}{|c|}{ Parameters } & Values \\
\hline SBP prior to treatment & $176.01 \pm 27.24$ \\
\cline { 2 - 2 } SBP after 2 weeks of treatment & $131.55 \pm 11.00^{*}$ \\
\hline DBP prior to treatment & $105.18 \pm 14.13$ \\
DBP after 2 weeks of treatment & $75.28 \pm 5.02^{*}$ \\
\hline $\begin{array}{l}\text { Mean BP prior to treatment } \\
\text { Mean BP after 2 weeks of treatment }\end{array}$ & $128.76 \pm 17.60$ \\
\hline $\begin{array}{l}\text { PP prior to treatment } \\
\text { PP after 2 weeks of treatment }\end{array}$ & $73.90 \pm 6.16^{*}$ \\
\hline HR prior to treatment & $55.94 \pm 10.039^{*}$ \\
HR after 2 weeks of treatment & $74.2 \pm 9.17$ \\
\hline Note: $*$ - p $<0.05$ vs levels before treatment & $76.73 \pm 4.82$ \\
\hline
\end{tabular}

\section{DISCUSSION}

The results obtained in the course of treatment with candesartan $(4 \mathrm{mg}, 8 \mathrm{mg}, 16 \mathrm{mg}$ ) combined with lacidipine $(2 \mathrm{mg}, 4 \mathrm{mg})$ can be explained by their mechanism of action.

Candesartan is an antihypertensive drug, a selective antagonist of the angiotensin II receptor ( $\mathrm{AT}_{1}$ type), a biphenyl tetrazole derivative by its molecular structure. The action of candesartan is based on the inhibition of the renin-angiotensinaldosterone system (RAAS) at the level of type 1 
angiotensin receptor $\left(\mathrm{AT}_{1}\right)$ for the angiotensin II (AT II).

In the RAAS cascade of reactions, AT II is having the leading effect being one of the most important vasoconstricting factors. Its damaging effect on the cardiovascular system, including myocardial hypertrophy and vascular remodeling, is mediated by $\mathrm{AT}_{1}$ receptor, the specific blockage of which causes antihypertensive as well as powerful organ-protecting effects [14].

The main mechanism of candesartan effect on the NO system in hypertensive patients was obviously connected to the blockage of $\mathrm{AT}_{1}$ receptors. These receptors transduct the AT II stimulatory effect on the formation of superoxide radicals, which react with NO binding it and forming a powerful oxidant - peroxynitrite. NO vasodilatory function is being lost in these conditions. Accumulation of endoperoxides in the endothelium has a damaging effect on it, thus leading to increased vascular permeability, proliferation, necrosis and capillary sclerosis $[14,15]$. Obviously, the blockage of $\mathrm{AT}_{1}$ receptors results in opposite - reduced production of superoxide radicals, reduced binding of $\mathrm{NO}$ and its increased accumulation [16, 17]. Along with this, the blockage of $\mathrm{AT}_{1}$ receptors contributes to enhanced $\mathrm{AT}_{2}$ receptor functioning. In the culture of endothelial cells, activating of the $\mathrm{AT}_{2}$ receptor has demonstrated the ability of angiotensin II to stimulate NO expression. Candesartan reduces the adverse effects of angiotensin II on the endothelium by attenuating the release of vasoconstrictive factors (including prostanoids, free oxygen radicals and endothelin-1), as well as increasing the release of NO from vascular cells, which increases the elasticity of the arteries.

Candesartan has a distinct advantage with respect to improving the elasticity of the arteries when compared to other groups of conventional antihypertensive drugs such as diuretics (D), $\beta$ blockers (BAB) and even calcium channel blockers (CCBs). Furthermore, it was found that high doses of ARA II express the additional vasoprotective effect, in contrast to the antihypertensive effect, which remains at the same level [18].

The obtained data suggests that $\mathrm{AT}_{1}$ receptor antagonist candesartan significantly increases the activity of NO expression processes in hypertensive patients with overweight and obesity. This fact is of great clinical importance, indicating that reducing the influence of AT II on tissues by blocking the $\mathrm{AT}_{1}$ receptor is not the only mechanism of this drug's action. An important contribution to the antihyper- tensive effect of candesartan is made by its impact on endothelial function and increasing NO production, manifested by increase of e-NOS activity.

The effect of candesartan on the state of vasoactive NO pool and activity of the antioxidant system is complemented by the action of lacidipine, a calcium channel blocker (CCB) of the third generation. It has been demonstrated previously that $\mathrm{CCB}$ can affect the endothelial function not only through a decrease in the $\mathrm{Ca}^{2+}$ concentration, but also through an increase in the NO production, which is a powerful vascular relaxing factor [19]. It was found that $\mathrm{CCB}$ are able to: 1) release the deposited NO $[20]$; 2) specifically enhance the expression of e-NOS; 3) enhance the stimulation effect of NO on the cyclic guanosine monophosphate (cGMP) expression which lowers the intracellular calcium concentration in the smooth muscles, leading to their relaxation and vasodilation; 4) store NO from its binding with $\mathrm{O}^{2-}$ to form peroxynitrite. [21]

Lacidipine is a dihydropyridine type CCB which has a pronounced selectivity of action to calcium channels located in vascular wall smooth muscle cells. The mechanism of its action is the dilation of peripheral arterioles, which reduces peripheral vascular resistance and blood pressure.

In the course of treatment of hypertensive patients with overweight and obesity, lacidipine inhibits the flow of $\mathrm{Ca}^{2+}$ in the slow L-type channels and reduces the intracellular concentration of this cation down to the normal level, causing a significant increase in the $\mathrm{Ca}^{2+}$-dependent e-NOS activity. At the same time, the formation of toxic peroxynitrite is being reduced in a result of antihypertensive treatment with candesartan/lacidipine combination, as increased SOD activity reduces the superoxide anion radicals level, and the level of 8-isoprostane, a marker of the OS, is significantly reducing. On the background of reduced oxidative stress which acts as a promotor of immune mechanisms mediated by pro-inflammatory cytokines, a decrease in TNF- $\alpha$ level with increase of sTNF$\alpha \mathrm{RI}$ is observed.

The experiment has shown that lacidipine regulated e-NOS genes expression and increased the level of e-NOS in aortic tissues [22, 23].

Anti-atherosclerotic (increase of cholesterol hydrolysis, decrease of intracellular lipids accumulation) and anti-proliferative (inhibition of the smooth muscle cells and macrophages migration and proliferation) effects of dihydropyridine type $\mathrm{CCB}$ are driven by the modulation of NO expression. $\mathrm{CCB}$ are considered to possess an anti-atherogenic 
effect due to their ability to interfere with processes that require the participation of calcium ions migration and proliferation of vascular smooth muscle cells, the monocytes movement towards the vascular intima and formation of foam cells, LDL oxidation and cholesterol metabolism. Lacidipine occupies a special place among the CCB, showing the most pronounced anti-atherosclerotic properties. Its antioxidant activity is comparable to one of vitamin $\mathrm{E}$ and exceeds that of all other CCB [24].

Lacidipine forms a stronger bond to the cell membrane compared to the other CCB. This determines its high local concentration in the blood vessels tissues (to which it is highly selective), which is particularly important in conditions of hypercholesterolemia, when the cell membrane's availability to $\mathrm{CCB}$ is decreased due to high cholesterol load. Lacidipine's binding to the cell membrane remains strong even in described conditions, being significantly higher than other CCB's [25]. The tight bond with the membrane defines a longer duration of lacidipine action and its ability to intervene in the majority of intracellular processes that take place in the early stages of atherogenesis.

According to Bernini F. [26], monocytes proliferation rate decreases by $64 \%$ under the influence of lacidipine. Neointimal formation also significantly slows down. In experiments on hypercholesterolemic rabbits, lacidipine slows post-operative (putting the cuff on the carotid artery) intimal thickening 2 times down [27]. Lacidipine is a potent inhibitor of smooth muscle cells migration: it completely prevents basal artery remodeling in spontaneously hypertensive rats [28]. The main role in the action of the drug on various links of the atherosclerotic process is given to its high vascular selectivity and the ability to tightly bind to the cell membrane in conjunction with an intense antioxidant effect and the ability to optimize the calcium homeostasis. Importantly, the anti-atherogenic effect of lacidipine is not determined by its antihypertensive effect: it is observed even when using lacidipine in low doses that do not affect blood pressure [24]. A close relation between the severity of the aortic atherosclerotic lesions and the content of endothelin in plasma of the $\mathrm{ApoE}^{-}$transgenic mice is widely used as a model of atherosclerosis. It is considered that the decrease in endothelin level is one of the mechanisms that determine the antiatherogenic effect of lacidipine. Endothelin plays a significant role in the process that "triggers" the onset and progression of atherosclerosis. Lacidipine reduces the pro-atherogenic effects of endothelin by suppressing its excessive expression.

In addition, as noted previously, lacidipine stimulates the production of endothelial $\mathrm{NO}$ by increasing the activity of e-NOS. In general, it testifies to the protective effect of lacidipine on endothelial function [24].

Thus, the assessment of endothelial function and pro-inflammatory cytokines activity allows to optimize the scheme of differentiated prescription of therapy in hypertensive patients.

\section{CONCLUSIONS}

1. A positive result in the treatment of hypertensive patients with overweight and obesity using the combination of antihypertensive drugs (lacidipine at a dose of $2 \mathrm{mg}, 4 \mathrm{mg}$ with candesartan at a dose of $4 \mathrm{mg}, 8 \mathrm{mg}, 16 \mathrm{mg}$ ) is associated with improved endothelial function. The latter is manifested by enhancement of endothelial NO-synthase activity and a simultaneous decrease of inducible NOsynthase.

2. This combination of lacidipine and candesartan reduces oxidative stress, which is expressed in the 8-isoprostane levels decrease as well as SOD and catalase activity increase.

3. Possessing a pronounced antioxidant and antiatherosclerotic properties, reducing the symptoms of endothelial dysfunction, a combination of candesartan and lacidipine significantly reduces the immune activation level, which is manifested in the reduction of TNF- $\alpha$ ratio to its type I soluble receptor (sTNF- $\alpha \mathrm{RI})$.

Conflict of interest. The authors declare no conflicts of interest.

Introducere. Obezitatea devine unul dintre principalii factori de risc pentru boala cardiacă coronară, hipertensiune şi accident vascular cerebral. Deşi pe piață există foarte multe medicamente antihipertensive nu putem considera că problema este ținută sub control. Unul din momentele cheie ale patogenezei hipertensiunii arteriale constă în disfuncția endotelială. La acest proces contribuie inflamația precum şi stresul oxidativ. 
Scop. Evaluarea efectului adițional benefic al unei terapii combinate antihipertensive cu lacidipină şi candesartan pe baza studiului proprietăților antioxidante, al impactului asupra funcției endoteliale şi asupra activității citokinelor proinflamatorii la pacienții cu hipertensiune şi obezitate.

Materiale şi metode. S-a prescris o combinație intre blocant de canal de calciu şi blocant de receptor al angiotensinei (lacidipină $2 \mathrm{mg}$, $4 \mathrm{mg}$ şi candesartan $4 \mathrm{mg}, 8 \mathrm{mg}$ şi $16 \mathrm{mg}$ ) la 30 de pacienți cu hipertensiune esențială gradele1-3, cu vârste cuprinse între 30-65 ani (vârsta medie $54.7 \pm 5.8$ ani). Pacienții nu primiseră inainte terapie antihipertensivă.

Rezultate. S-a observat o scădere semnificativă a activității $i$-NOS, a raportului seric TNF- $\alpha /$ STNF- $\alpha R I$ (receptorul solubil I al TNF- $\alpha$ ), şi a markerului de stres oxidativ 8-iso-PgF2 $\alpha$. In schimb activitatea e-NOS, nivelul SOD şi al catalazei au crescut la finalul perioadei de observație.

Concluzii. La pacienții hipertensivi, obezi tratați cu lacidipină şi candesartan s-a observat o îmbunătățire a funcției endoteliale datorate scăderii stresului oxidativ si o scădere semnificativă a activării imunologice.

Correspondence to: Nina Gerasimchuk, Kharkiv National Medic University,

Nauky Ave., 4, Kharkiv, 61022, Ukraine, Tel.: +38-096-120-68-72.

E-mail: nino.gerasimchuk@gmail.com

\section{REFERENCES}

1. RUILOPE LM. Renal function and cardiovascular risk in hypertensive patients. J Hypertension. 2005; 23(10): 1787-8.

2. DYER AR., ELLIOTT P., STAMLER SR., STAMLER J. Body mass index and association of sodium and potassium with blood pressure in LNTERSALT. Hypertension. 1994; 23:729-6.

3. NUSSINOVITCH U. The Heart in Rheumatic, Autoimmune and Inflammatory Disease Pathophysiology, Clinical Aspects and Therapeutic Approaches. Academic Press, 2017: 766.

4. KOVALYOVA O., BELOVOL A., ZAYIKA M. The role of oxidative stress in cardiovascular disease. J Academy of Medical Sciences of Ukraine. 2005; 11(4): 660-70.

5. KOVALYOVA O., ASHCHEULOVA T. Tumor necrosis factor- $\alpha$, apoptosis in the pathology of cardiovascular system. Original, Kharkiv, 2003: 95.

6. KOVALYOVA O., ASHCHEULOVA T., GERASIMCHUK N. Relationship of immune activation and oxidative stress in patients with hypertension and their correction combined antihypertensive therapy. Scientific bulletin BelSU Medicine Pharmacy. 2015; 16 (213) Issue 31: 52-9.

7. KOVALYOVA O., SHAPOVALOVA S., GERASIMCHUK N. Combination therapy of hypertension. Pleiad, Kharkiv, $2005: 48$.

8. KOVALENKO V., NESUKAY E., YAKOVENKO A. Problems of diagnosis and management of patients with metabolic syndrome. Ukrain J of Cardiology, 2006; 4: 98-105.

9. SIRENKO Y. Dihydropyridine calcium channel blockers - a new provision to reduce the risk of complications of hypertension. J News of medicine and pharmacy. 2009; 18 (292): 3-4.

10. MANCIA G., FAGARD R., NARKIEWICZ K., et al. 2013 ESH/ESC Guidelines for the management of arterial hypertension: The Task Force for the management of arterial hypertension of the European Society of Hypertension (ESH) and of the European Society of Cardiology (ESC). European Heart J. 2013; 34(28): 2159-2219.

11. WORLD HEALTH ORGANIZATION. Obesity: preventing and managing the global epidemic. WHO Technical Report Series. 2000: 1-252.

12. KOVAlYOVA O., ASHCHEUlOVA T., GERASIMCHUK N., SAFARGALINA-KORNILOVA N. The role of oxidative stress in the formation and progression of hypertension. Scientific bulletin BelSU Medicine Pharmacy. 2015; 4(201) Issue 29: 5-10.

13. LEONETTI G., MAGNANI B., RAPPELLI A., TRIMARCO B., ZANCHETTI A. et al. Tolerability of long-term treatment with lercanidipine versus amlodipine and lacidipine in elderly hypertensives. Amer J Hypertension. 2002; 15(11): 932-940.

14. CHUNG O., UNGER T. Angiotensin II receptor blockade and end organ protection. Amer J Hypertension. 1999; 12:150-156.

15. RUIZ-ORTEGA M., LORENZO O., SUZUKI Y., RUPÉREZ M., EGIDO J. Proinflammatory actions of anqiotensin $\Pi$. Curr Opin Nephrol Hypertens. 2001; 10(3): 321-9.

16. ASHCHEULOVA T. Comparative characteristics of the clinical efficacy of inhibitors of the renin-angiotensin system in hypertension: Impact on biomarkers of systemic inflammation. Medical practice. 2007; 3:48-51.

17. AMBROSOVA T., KOVALYOVA O., ASHCHEULOVA T. Therapeutic potential angiotensin II receptor antagonists in patients with arterial hypertension with metabolic disorders: effect on carbohydrate and lipid profili. Ukrainian Therapeutical J. $2010 ; 4: 17-22$. 
18. SHARGORODSKY M., HASS E., BOAZ M., GAVISH D., ZIMLICHMAN R. High dose treatment with angiotensin II receptor blocker in patients with hypertension: Differential effect of protection versus blood pressure lowering. J Atherosclerosis. 2008; 197(1): 303-310.

19. MITCHENKO E.. GULAYA N., VIKTOROV A. Use of calcium antagonists and NO-state change in patients with hypertension. Ukrain J of Cardiology 2000; 1-2: 49-55.

20. ZHANG X., HINTZE T.H. Amlodipine releases nitric oxide from canine coronary microvessels: an unexpected mechanism of action of a calcium channel-blocking agent. Circulation. 1998; 97(6): 576-580.

21. BLACK S.M., FINEMAN J.R., STEINHORN R.H., BRISTOW J., SOIFER S.J. Increased endothelial NOS in lambs with increased pulmonary blood flow and pulmonary hypertension. Am J Physiol Soc.1998; 275(5): 1643-1651.

22. TADDEI S., VIRDIS A., GHIADONI L., ULERI S., MAGAGNA A., SALVETTI A. Lacidipine restores endotheliumdependent vasodilation in essential hypertensive patients. J Hypertension. 1997; 30(6): 1606-1612.

23. KRENEK P., SALOMONE S., KYSELOVIC J., WIBO M., MOREL N., GODFRAIND T. Lacidipine Prevents Endothelial Dysfunction in Salt Loaded Stroke Prone Hypertensive Rats. J Hypertension. 2001; 37: 1124-1128.

24. SVISCHENKO E. Anti-atherogenic effect of lacidipine: study ELSA (European Lacidipine Study on Atherosclerosis). Medicine svitu. 2002.

25. HERBETTE L.G. The interaction of Lacidipine with Biological Membranes: The Molecular of Calcium Antagonists. Rev Contemp Pharmacother. 1995; 6(1): 8 .

26. BERNINI F., CORSINI A., RAITERI M., SOMA M. R., PAOLETTI R. Effects of Lacidipine on Experimental Models of Atherosclerosis. J of Hypertension. 1993; 11(suppl 1): 61-66.

27. SOMA M.R. Calcium Antagonists in atherosclerosis: Focus on Lacidipine. Resesrch and Clinical Forums. 1994; 6(1): P. $543-551$.

28. GODFRAIND T. Effect of calcium antagonist in preclinical models of atherosclerosis. The ELSA study results. ADIS. $2002 ; 6-7$.

Received April 12, 2018 